\title{
Exenatide efficacy in unselected patients: Comparison with clinical trials
}

\author{
Carole Collet-Gaudillat", Gwenaelle Petit-Aubert, Virginie Desforges-Bullet, Jean Paul Beressi
}

Service de Diabétologie Endocrinologie, Hôpital André Mignot, Le Chesnay, France;

*Corresponding Author: ccollet@ch-versailles.fr

Received 3 October 2011; revised 14 November 2011; accepted 28 November 2011

\begin{abstract}
Exenatide is a Glucagon-Like Peptide-1 (GLP-1) analog improving fasting and post-prandial glycaemia, approved in patients treated with a combination of sulfonylureas and metformin and not achieving good metabolic control. This retrospective cohort study compared the efficacy and safety of exenatide in unselected patients with outcomes of FDA trials and other uncontrolled published studies. Exenatide was prescribed in 108 patients between April 2008 and December $2009,80 \%$ of the patients were treated with $10 \mu \mathrm{g}$ of exenatide twice daily. Mean follow up was 4.5 months for the 1st follow up. Changes in HbA1c $(-1.1 \%)$, BMI $(-1.1)$ and fasting glucose $(-0.61 \mathrm{~g} / \mathrm{l})$ from baseline were significant, and coherent with controlled trials. $32 \%$ of patients had at least one side effect, often gastro intestinal. $23 \%$ stopped the treatment, a quarter (1/4) of which for inefficacity. Patients with a higher BMI $(>40)(n=29)$ at baseline did not show a better response in HbA1c or weight. Results at the second follow-up show a slight tendency of rising on HbA1c, BMI and fasting blood glucose. Finally, a third follow-up at a mean of 17 months is available for 11 patients, which shows stability in HA1c, BMI and fasting glucose. In our experience, Exenatide was safe and effective in reducing $\mathrm{HbA} 1 \mathrm{c}$ and weight in patients who were able to tolerate it. Our results are close to results published elsewhere. There are still gaps in the literature on exenatide, especially on the long term effect, which need to be assessed by more publications.
\end{abstract}

Keywords: Diabetes Mellitus; Exenatide; Long Term Effect

\section{INTRODUCTION}

Treatment of type 2 diabetes is challenging because of the progressive nature of the disease. A combination of insulin resistance and insulin deficiency occurs at different stages in time, with a marked link with obesity. Half of type 2 diabetes patients require more than one oral anti-diabetic drug (OAD) within 3 years from diagnosis and combination oral therapy with or without insulin therapy within 6 to 9 years from diagnosis [1]. Exenatide was the first incretin mimetic agent released in France, in April 2008. It was approved for use in combination with metformin and sulfonylureas for patients not achieving adequate glycaemic control on maximal tolerated dose of OAD. Exenatide is an incretin and a Glucagon-Like Peptide -1 (GLP-1) analog improving fasting and post-prandial glycaemia by inducing glucosedependant insulin secretion and suppressing glucagon secretion from the pancreas. It also delays gastric emptying and induces early satiety [2]. Exenatide was first FDA (Food and Drug Administration) Approved in November 2006 after the publication of 3 short term studies conducted by the manaufacturer [3-5]. The objective of this study was to compare the efficacy and safety of exenatide in unselected patients with outcomes of FDA trials and other uncontrolled published studies [6-9].

\section{METHODS}

This retrospective cohort study used the medical database of our community hospital diabetes department, ranging from April 2008 to December 2009. Permission to review patients' data was obtained from the local institutional review board. Medical record was detailed at baseline for age, sex, type and duration of diabetes, associated treatment for diabetes before starting exenatide, weight, height and BMI, HbA1c and fasting glycaemia, self monitoring of blood glucose and self-reported episodes of hypoglycaemia. Follow-up was divided in 3 periods: $1^{\text {st }}$ period: first six months, $2^{\text {nd }}$ period: six to twelve months, $3^{\text {rd }}$ period: more than 12 months. We evaluated number lost to follow-up, exenatide dose effectively done, mean follow-up in months, changes in weight, BMI, HbA1c and fasting glycaemia, associated 
treatment for diabetes, self-reported hypoglycaemia, side effects and withdrawal or not of treatment. The paired and unpaired t-test were used to compare means and proportions, with significance set at $\mathrm{p}<0.05$.

\section{RESULTS}

Exenatide was prescribed in 108 patients between April 2008 and December 2009. Main data are shown in Table 1. Follow-up in the $1^{\text {st }}$ period is available for 91 patients (16\% lost to follow-up). Medical baseline records of "lost to follow-up patients" did not differ significantly from patients with at least one follow-up (data not shown). $80 \%$ of the patients were treated with $10 \mu \mathrm{g}$ of exenatide twice daily. Mean follow up was 4.5 months for this group. Changes in HbA1c $(-1.1 \%)$, BMI $(-1.1)$ and fasting glucose $(-0.61 \mathrm{~g} / \mathrm{l})$ from baseline were significant. $32 \%$ of patients had at least one side effect, most of them of the gastro intestinal type. 23\% stopped the treatment, 1/4 of which for inefficacity. Patients with a higher BMI $(>40)(n=29)$ at baseline did not show a better response in $\mathrm{HbA} 1 \mathrm{c}$ or loss of weight. A second follow-up is available for 38 patients, at 10.5 months. 17 patients will stop the treatment at this stage, 9 for inefficacity. HbA1c, BMI and fasting blood glucose show a slight tendency of rising. Finally, a third follow-up at a mean of 17 months is available for 11 patients, which shows stability in $\mathrm{HbA} 1 \mathrm{c}$, BMI and fasting glucose.

\section{DISCUSSION}

In our experience, Exenatide was safe and effective in reducing $\mathrm{HbAlc}$ and weight in patients who were able to tolerate it. The results observed are very similar to the one published in 2 randomised trials of 6 months duration resumed in Table 2. There is no controlled data for a longer period, but extension studies of controlled 6 months studies show maintenance of the control of blood glucose at one year. Gain in HbAlc and weight were similar at 6 months and one year: $-0.8 \%$ to $1 \%$ in $\mathrm{HbAlc}$ and -2.5 to $-3.6 \mathrm{kgs}$. Reductions in weight and $\mathrm{HbAlc}$ with exenatide are even greater when uncontrolled studies are taken into account (data shown in Table 3). Therefore, we didn't observe the same results for the weight in our population, but the limited number of subjects with a long follow up is probably responsible for this difference, with no statistical significance. Limitations inherent to retrospective manner are important, because some side effects can be omitted inadvertently for example, despite the use of a standardised query form and few patients have a long follow up. Inclusion of patients completing the follow up can induce a favoring bias. In our study, patients lost to follow up had no clinical differences compared to patients with at least one follow up. Long term data are difficult to obtain, for example in the one year follow up study published par M. Buysschaert and al. 77 patients on 299 included stopped

Table 1. Follow-up of patients treated with exenatide between April 2008 and December 2009.

\begin{tabular}{|c|c|c|c|}
\hline Characteristics ( $\Delta$ from baseline) & Follow up $1 \mathrm{n}=91$ & Follow up $2 \mathrm{n}=38$ & Follow up $3 \mathrm{n}=11$ \\
\hline Lost to follow up & $17(15.7 \%)$ & 10 & 1 \\
\hline Mean follow up (months) & $4.5 \pm 2.6$ & $10.3 \pm 3.6$ & $17.1 \pm 3.9$ \\
\hline $\begin{array}{c}\text { HbAlc }(\%) \\
\text { Fasting glucose }(\mathrm{g} / \mathrm{l})\end{array}$ & $\begin{array}{c}7.6 \pm 1.2: \Delta-1.26, p<0.0001 \\
1.64 \pm 0.51: \Delta-0.21, p=0.06 \mathrm{~ns}\end{array}$ & $\begin{array}{c}8.1 \pm 1.4: \Delta-\mathbf{0 . 7 6 , p}=\mathbf{0 . 0 2 0} \\
1.9 \pm 0.6: \Delta-\mathbf{0 . 1 3}, \mathbf{p}=\mathbf{0 . 2 6}\end{array}$ & $\begin{array}{c}8.5 \pm 1,3: \Delta-\mathbf{0 . 7 0}, \mathbf{p}=\mathbf{0 . 0 7} \mathbf{n s} \\
1.9 \pm 0.59: \Delta-\mathbf{0 . 1 1}, \mathbf{p}=\mathbf{0 . 6 7} \mathbf{n s}\end{array}$ \\
\hline Associated treatment for diabetes & Met + SH: $90 \%$ & Met+ SH: $91 \%$ & Met+ SH: $81 \%$ \\
\hline Hypoglycaemias (self-reported): & $\begin{array}{c}\text { none: } 72(79 \%) \\
\text { 1/month: } 5(5.5 \%) \\
\text { 1/week or more: } 5(5.5 \%)\end{array}$ & $\begin{array}{c}\text { none: } 34 \\
\text { 1/month: } 1 \\
\text { 1/ week or more: } 0\end{array}$ & $\begin{array}{c}\text { none: } 10 \\
\text { 1/month: } 0 \\
\text { 1/ week or more: } 1\end{array}$ \\
\hline Side effects: & $\begin{array}{l}\text { Yes: } 30 \text { patients }(33 \%) \\
\text { No: } 61 \text { patients }(67 \%)\end{array}$ & $\begin{array}{l}\text { Yes: } 12 \text { patients }(31 \%) \\
\text { No: } 26 \text { patients }(69 \%)\end{array}$ & $\begin{array}{l}\text { Yes: } 2 \text { patients }(11 \%) \\
\text { No: } 9 \text { patients }(89 \%)\end{array}$ \\
\hline Side effect type (n) & $\begin{array}{c}\text { Gastro-intestinal: } 22 \\
\text { Hypoglycaemia: } 1 \\
\text { Neurologic: } 2 \\
\text { Other: } 5\end{array}$ & $\begin{array}{c}\text { Gastro-intestinal:10 } \\
\text { Hypoglycaemia : } 1 \\
\text { Neurologic:0 } \\
\text { Other: } 1\end{array}$ & $\begin{array}{c}\text { Gastro-intestinal: } 1 \\
\text { Hypoglycaemia: } 1 \\
\text { Neurologic:0 } \\
\text { Other: } 0\end{array}$ \\
\hline $\begin{array}{l}\text { Withdrawal Causes for stopping } \\
\qquad(\% / \text { total patient })\end{array}$ & $\begin{array}{c}23 \% \\
\text { Inefficacity: } 5.5 \% \\
\text { Side effects: } 15.4 \% \\
\text { Other: } 3.3 \%\end{array}$ & $\begin{array}{c}44 \% \\
\text { Inefficacity: } 26 \% \\
\text { Side effects: } 21 \% \\
\text { Other: } 2.5 \%\end{array}$ & $\begin{array}{c}6 \% \\
\text { Inefficacity:9\% } \\
\text { Side effects: } 0 \% \\
\text { others: } 9 \%\end{array}$ \\
\hline
\end{tabular}


Table 2. Controlled studies.

\begin{tabular}{|c|c|c|c|c|}
\hline Study & $\begin{array}{l}\text { Effects of exenatide on } \\
\text { glycemic control over } 30 \text { weeks in } \\
\text { patients with } \\
\text { type } 2 \text { diabetes treated with } \\
\text { metformin and a sulfonylurea, }\end{array}$ & $\begin{array}{l}\text { Exenatide efficacy and } \\
\text { safety: a systematic review }\end{array}$ & $\begin{array}{l}\text { One year treatment with } \\
\text { exenatide improves Beta } \\
\text { cell function, compared } \\
\text { with insulin glargine, } \\
\text { in metformin treated } \\
\text { type } 2 \text { diabetic patients }\end{array}$ & $\begin{array}{l}\text { A comparison of twice } \\
\text { daily exenatide and } \\
\text { biphasic insulin aspart } \\
\text { in patients with type } 2 \\
\text { diabetes: a non } \\
\text { sinferiority study }\end{array}$ \\
\hline $\begin{array}{l}\text { Authors } \\
\text { Journal }\end{array}$ & $\begin{array}{l}\text { D.M. Kendall, M.C. Riddle, J. } \\
\text { Rosenstock, et al. } \\
\text { Diabetes Care } 28 \text { (2005) } \\
1083-1091\end{array}$ & $\begin{array}{l}\text { S.L.Norris, N.Lee, } \\
\text { S.Thakurta, B.K.S Chan } \\
\text { Diabetic Medicine } 26 \\
\text { (2009) } 837-846\end{array}$ & $\begin{array}{l}\text { M.C.Bunck, M.Dianmant, } \\
\text { A.Corner et al. } \\
\text { Diabetes Care } 32(2009) \\
762-768\end{array}$ & $\begin{array}{l}\text { M.A. Nauck, S.Duran, } \\
\text { D.Kim et al. } \\
\text { Diabetologia } 50 \text { (2007) } \\
\text { 259-267 }\end{array}$ \\
\hline $\begin{array}{c}\text { Type of study } \\
\text { Number of Subjects }\end{array}$ & $\begin{array}{l}\text { Randomised controlled versus } \\
\text { placebo } \\
593\end{array}$ & $\begin{array}{c}\text { Metaanalysis } 4 \text { randomised } \\
\text { studies vs. placebo } \\
1539\end{array}$ & $\begin{array}{c}\text { Open study } \\
36 \text { exenatide versus } 33 \\
\text { glargine }\end{array}$ & $\begin{array}{c}\text { Non inferiority } \\
\text { open study } 253 \\
\text { exenatide vs. } 248 \text { glargine }\end{array}$ \\
\hline $\begin{array}{c}\text { Age } \\
\text { Sex (\% men) } \\
\text { Follow up }\end{array}$ & $\begin{array}{l}53.6 \pm 5.7 \\
58 \\
6.5 \text { months }\end{array}$ & $\begin{array}{c}55 \\
58 \\
5.5 \text { months }\end{array}$ & $\begin{array}{c}58.4 \\
63 \\
12 \text { months }\end{array}$ & $\begin{array}{c}58 \\
56 \\
12 \text { months }\end{array}$ \\
\hline $\begin{array}{l}\text { Baseline BMI }\left(\mathrm{kg} / \mathrm{m}^{2}\right) \\
\text { Loss of weight }(\mathrm{kg})\end{array}$ & $\begin{array}{c}33.6 \pm 6 \\
-1.6 \pm 0.2\end{array}$ & $\begin{array}{c}34 \\
-1.25\end{array}$ & $\begin{array}{c}30.9 \\
\text { (exenatide) } \\
-3.6\end{array}$ & $\begin{array}{c}30.2 \\
\text { (exenatide) } \\
-2.5\end{array}$ \\
\hline $\begin{array}{c}\text { Baseline HbA1c }(\%) \\
\text { Changes in HbA1c }\end{array}$ & $\begin{array}{c}8.5 \pm 1 \\
-0.80 \pm 0.1\end{array}$ & $\begin{array}{c}8.3 \\
-0.9\end{array}$ & $\begin{array}{c}7.6 \\
\text { (exenatide) } \\
-0.8\end{array}$ & $\begin{array}{c}\mathbf{8 . 6} \\
\text { (exenatide) } \\
-\mathbf{1 . 0 4} \pm \mathbf{0 . 0 7}\end{array}$ \\
\hline $\begin{array}{c}\text { Side effects } \\
\text { Nausea (\%) } \\
\text { Hypoglycaemia } \\
\text { withdrawal }\end{array}$ & $\begin{array}{l}45 \% \\
36 \% \\
15 \%\end{array}$ & $\begin{array}{l}\text { RR X } 2.8 \text { vs. placebo } \\
\text { RR X } 2.4 \text { vs. placebo } \\
\text { RR X } 3.4 \text { vs. placebo }\end{array}$ & $\begin{array}{c}50 \% \\
8.3 \% \\
16 \%\end{array}$ & Data not available \\
\hline
\end{tabular}

Table 3. Main results in uncontrolled studies.

\begin{tabular}{|c|c|c|c|}
\hline Study & $\begin{array}{l}\text { Six-month outcomes on A1C } \\
\text { and cardiovascular risk factors } \\
\text { in patients with type } 2 \text { diabetes } \\
\text { treated with exenatide in an } \\
\text { ambulatory care setting }\end{array}$ & $\begin{array}{l}\text { Effectiveness of the novel } \\
\text { anti-diabetes medication } \\
\text { exenatide in everyday practice: } \\
\text { Comparison with clinical trials }\end{array}$ & $\begin{array}{l}\text { One-year metabolic outcome in } \\
\text { patients with type } 2 \text { diabetes } \\
\text { treated with exenatide in } \\
\text { routine practice }\end{array}$ \\
\hline $\begin{array}{l}\text { Authors } \\
\text { Journal }\end{array}$ & $\begin{array}{l}\text { D. I. Brixner, C. McAdam-Marx, } \\
\text { X. Ye, et al. } \\
\text { Diabetes, Obesity and } \\
\text { Metabolism } 11(2009) \\
1122-1130\end{array}$ & $\begin{array}{l}\text { Sirisha Donekal, Mansur E. } \\
\text { Shomali } \\
\text { Diabetes research and clinical } \\
\text { practice } 80(2008) \text { e4-e6 }\end{array}$ & $\begin{array}{l}\text { M. Buysschaert, V. Preumont, P. R. } \\
\text { Oriot et al. } \\
\text { Diabetes \&Metabolism } 36 \text { (2010) } \\
\text { 381-388 }\end{array}$ \\
\hline $\begin{array}{c}\text { Type of study } \\
\text { Number of Subjects }\end{array}$ & $\begin{array}{c}\text { Retrospective study } \\
1709\end{array}$ & $\begin{array}{l}\text { Retrospective } \\
81\end{array}$ & $\begin{array}{l}\text { Observational retrospective study } \\
94\end{array}$ \\
\hline $\begin{array}{c}\text { Age } \\
\text { Sex (\% men) } \\
\text { Follow up }\end{array}$ & $\begin{array}{c}55.4 \pm 10.5 \\
41 \\
6 \text { months }\end{array}$ & $\begin{array}{c}55 \pm 11 \\
45 \\
6 \text { months }\end{array}$ & $\begin{array}{c}59 \pm 11 \\
56 \\
12 \text { months }\end{array}$ \\
\hline $\begin{array}{c}\text { Baseline BMI }\left(\mathrm{kg} / \mathrm{m}^{2}\right) \\
\text { Loss of weight }(\mathrm{kg})\end{array}$ & $\begin{array}{c}38.8 \pm 8 \\
-3.2\end{array}$ & $\begin{array}{c}41 \pm 11 \\
-4.3 \pm 4\end{array}$ & $\begin{array}{l}\mathbf{3 4 . 5} \pm 6.8 \\
\quad-4.9\end{array}$ \\
\hline $\begin{array}{c}\text { Baseline HbA1c }(\%) \\
\text { Changes in HbA1c }\end{array}$ & $\begin{array}{c}8.4 \pm 1.2 \\
-0.79\end{array}$ & $\begin{array}{c}8.0 \pm 2 \\
-1.2 \pm 1.7\end{array}$ & $\begin{array}{l}9.1 \pm 1.4 \\
\quad-1.6\end{array}$ \\
\hline $\begin{array}{c}\text { Side effects } \\
\text { Nausea (\%) } \\
\text { Hypoglycaemia } \\
\text { Withdrawal }\end{array}$ & not available & $\begin{array}{c}12 \% \\
6 \% \\
\text { Data not available }\end{array}$ & $\begin{array}{l}33 \% \\
3.5 \% \\
27 \%\end{array}$ \\
\hline
\end{tabular}

the treatment before the end of the study and 12 months data was available for 94 patients over all.

Data on a longer duration (2 year extension open label study) concern a limited number of very selected patients (approximatively $25 \%$ of patients initially included in 6 months controlled versus placebo studies [9]). Most of controlled studies were funded by the pharmaceutical industry or had at least one author affiliated with industry, and there is empirical data suggesting that industry funded studies are potentially biased towards the agent 
they test. Data are shown in table 2. Patients included in controlled studies are often very selected patients, who accept twice daily injections and close follow up. Proofs of a sustained effect of exenatide in time are still lacking. And in our experience, there seems to be a loss of efficacy with time, which needs to be confirmed or not by other independent publications.

\section{CONCLUSION}

In summary, efficacy and tolerability of exenatide in "real care" setting are similar than in short term controlled studies, but data in the long term are still lacking. Patients offered to be treated with exenatide often ask their practitioner "for how long should I use this treatment?" and there is still no answer to that.

\section{REFERENCES}

[1] Turner, R.C., Cull, C.A., Frighi, V. and Holman, R.R. (1999) Glycemic control with diet, sulfonylurea, metformin, or insulin in patients with type 2 diabetes mellitus: Progressive requirement for multiple therapies (UKPDS 49). UK Prospective Diabetes Study (UKPDS) Group. Journal of the American Medical Association (JAMA), 281, 2005-2012. doi:10.1001/jama.281.21.2005

[2] Iltz, J.L., Baker, D.E., Setter, S.M. and Keith Campbell, R. (2006) Exenatide: An incretin mimetic for the treatment of type 2 diabetes mellitus. Clinical Therapeutics, 28, 652-665. doi:10.1016/j.clinthera.2006.05.006

[3] Buse, J.B., Henry, R.R., Han, J., Kim, D.D., Fineman, M.S., Baron, A.D. and Exenatide-113 Clinical Study Group (2004) Effects of exenatide (exendin-4) on glycemic control over 30 weeks in sulfonylurea-treated patients with type 2 diabetes. Diabetes Care, 27, 2628-2635. doi:10.2337/diacare.27.11.2628

[4] DeFronzo, R.A., Ratner, R.E., Han, J., Kim, D.D., Fineman, M.S. and Baron, A.D. (2005) Effects of exenatide (exendin-4) on glycemic control and weight over 30 weeks in metformin-treated patients with type 2 diabetes. Diabetes Care, 28, 1092-1100. doi:10.2337/diacare.28.5.1092

[5] Kendall, D.M., Riddle, M.C., Rosenstock, J., Zhuang, D., Kim, D.D., Fineman, M.S. and Baron, A.D. (2005) Effects of exenatide (exendin-4) on glycemic control over 30 weeks in patients with type 2 diabetes treated with metformin and a sulfonylurea. Diabetes Care, 28, 10831091. doi:10.2337/diacare.28.5.1083

[6] Norris, S.L., Lee, N., Thakurta, S. and Chan, B.K. (2009) Exenatide efficacy and safety: A systematic review. Diabetic Medicine, 26, 837-846. doi:10.1111/j.1464-5491.2009.02790.x

[7] Donekal, S. and Shomali, M.E. (2008) Effectiveness of the novel anti-diabetes medication exenatide in everyday practice: Comparison with clinical trials. Diabetes Research and Clinical Practice, 80, e4-e6. doi:10.1016/j.diabres.2008.01.014

[8] Brixner, D.I., McAdam-Marx, C., Ye, X., Boye, K.S., Nielsen, L.L., Wintle, M., Misurski, D. and Fabunmi, R. (2009) Six-month outcomes on A1C and cardiovascular risk factors in patients with type 2 diabetes treated with exenatide in an ambulatory care setting. Diabetes, Obesity and Metabolism, 11, 1122-1130. doi:10.1111/j.1463-1326.2009.01081.x

[9] Buse, J.B., Klonoff, D.C., Nielsen, L.L., Guan, X., Bowlus, C.L., Holcombe, J.H., Maggs, D.G. and Wintle, M.E. (2007) Metabolic effects of two years of exenatide treatment on diabetes, obesity, and hepatic biomarkers in patients with type 2 diabetes: An interim analysis of data from the open-label, uncontrolled extension of three double-blind, placebo-controlled trials. Clinical Therapeutics, 29, 139-153. doi:10.1016/j.clinthera.2007.01.015 